
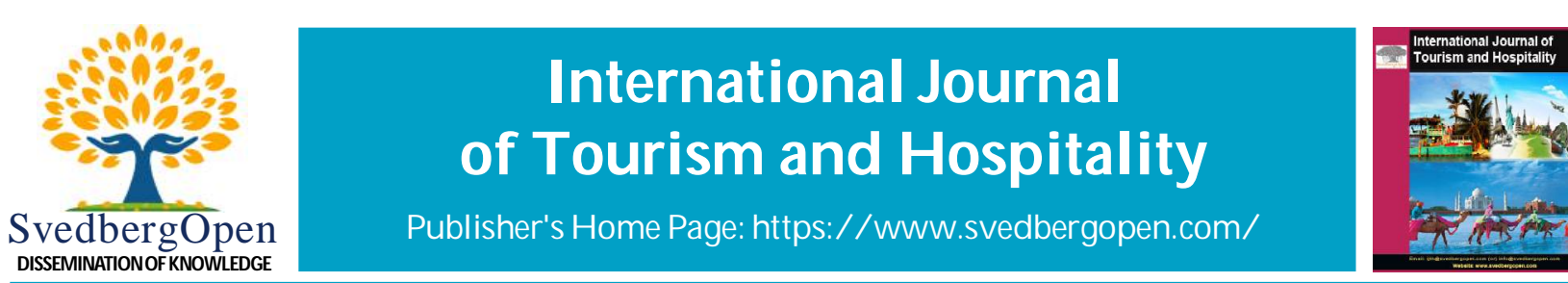

Research Paper

O pen A ccess

\title{
Impact of empiris profitability, growth, size firm, tangibility on capital structure of the hotel industry
}

\author{
Siti Awaliyah ${ }^{1 *}$, Dhimas Anggono ${ }^{2}$, Tantri Yanuar Rahmat Syah ${ }^{3}$ and Eka Bertuah ${ }^{4}$ \\ ${ }^{1}$ Master of Management, Faculty of Economics and Business, Esa Unggul University, Jakarta. E-mail: Bundalia783@gmail.com \\ ${ }^{2}$ Master of Management, Faculty of Economics and Business, Esa Unggul University, Jakarta. E-mail: dhimas.negoro@mahagatra.com \\ ${ }^{3}$ Master of Management, Faculty of Economics and Business, Esa Unggul University, Jakarta. E-mail: Tantri.Yanuar@esaunggul.ac.id \\ ${ }^{4}$ Master of Management, Faculty of Economics and Business, Esa Unggul University, Jakarta. E-mail: eka.bertuah@esaunggul.ac.id
}

\section{Article Info}

Volume 1, Issue 2, April 2021

Received : 04 January 2021

Accepted : 29 March 2021

Published : 05 April 2021

doi: 10.51483/IJTH.1.2.2021.21-33

\begin{abstract}
The current state of the tourism industry is being hit by the Covid pandemic which has caused the industry to collapse so that the performance of this industry must begin to tighten its operations in the face of the Covid-19 pandemic crisis. In assessing the financial performance of the hospitality business, investors learn a lot about the factors shown by the financial statements of each hospitality institution such as profitability, firm size and growth and its tangibility so that investors can determine how profitable this business is. The purpose of this study is to analyze influence of Return on Asset (ROA), growth, size firm, tangibility on Debt to Equity Ratio (DER) as well as influence between ROA and firm size against DER, sample research on 18 hospitality companies in Indonesia shows that ROA has no positive effect on DER, for growth has a negative effect on DER, firm size and tangibility has a positive effect on DER. From this result, investors are expected to obtain information and references in investing in the hospitality industry so that investors will benefit.

Keywords: Capital structure, Return on Asset (ROA), Growth, Size firm, Tangibility, DER

C) 2021 International Journal of Tourism and Hospitality. This is an open access article under the CC BY license (https://creativecommons.org/licenses/by/4.0/), which permits unrestricted use, distribution, and reproduction in any medium, provided you give appropriate credit to the original author(s) and the source, provide a link to the Creative Commons license, and indicate if changes were made.
\end{abstract}

\section{Introduction}

Capital structure is one of the most important things in financial decision making, because it is related to other financial decision variables (Gitman and Zutter, 2012). It is therefore important for enterprises to know how to use optimal capital structure (Brigham and Joel, 2011). It is the responsibility of the management of the company to determine the proper capital structure and ensure that their business continues to run smoothly. Most economies in developing countries are uncertain, so capital decision decisions are very important because of macroeconomic factors such as high interest rates and soaring, inflation, volatility in economic and political situations, and epidemics are important factors that determine corporate capital structure (Ajao et al., 2012). The combination of capital structure is either determined by the company's ability to generate profit or called profitability from the business activities performed.

Some research and academics before has long been interested in problems examine the relationship of profitability, growth, firm size and tangibility to capital structure such as research conducted by Thippayana (2014) which examined

\footnotetext{
* Corresponding author: Siti Awaliyah, Master of Management, Faculty of Economics and Business, Esa Unggul University, Jakarta. E-mail: Bundalia783@gmail.com
} 
the capital structure determinants of 144 firms on the Thai stock exchange with a period of 12 years from 2000 to 2011 with dependent capital structure variables and firm firm size variables, profitability, tangibility, growth opportunity, and volatility. Alipour et al. (2015) in his empirical study related to the determinants of the capital structure of manufacturing companies listed on the Iranian Tehran stock exchange during the period 2003 to 2007 with dependent variables of capital structure and independent variables of effective tax rates, firm size, liquidity, financial flexibility, stock price performance, asset structure, growth opportunities, risk, profitability, asset utilization ratios, and ownership structure. Detthamrong et al. (2017) in his research on the size of companies affecting the capital structure measured by the Debt to Equity Ratio (DER) in private companies in Thailand. Baloch et al. (2015) in a study of the impact of company size, tangibility of assets affecting DER in 22 companies in the automotive sector of Pakistan.

Sakr and Bedeir (2019) in his journal he explained about the factors that determine the level of companies from the capital structure of 62 Egyptian companies from 2003-2016. With dependent variables of capital structure and independent variables of profitability, size, manifestations, liquidity, growth, business risk and financial flexibility. Kartikasari and Merianti (2016) conducted a study on the impact of profitability on capital structure in 100 manufacturing companies in Indonesia period 2009-2014. Fajrida and Br.Purba (2020) do research simultaneous between the variables of profitability, size, growth of corporate assets against the capital structure of manufacturing companies in Indonesia period 2007-2014.

Baloch et al. (2015), at the end of his research stated the need for future studies to include other variables related to capital structure as well as research in other sectors. Kartikasari and Merianti (2016) also questions what other variables affect the capital structure of the company, thus strengthening further research.

From previous research has been extensively examined the influence of profitability variables, growth, size firm on capital structure, however there is no comprehensive research that examines the factors of profitability, growth, size firm, tangibility and macroeconomic mediation variables we conducted comprehensive research with the hospitality industry sector in Indonesia with a research period of 2014-2019.

The purpose of this study was to determine the empirical relationship of influence of profitability, growth, firm size, tangibility to capital structure and how the influence of inflation moderation variables affect profitability on capital structure, and firm size on capital structure. By understanding this research is expected to investors to be able to choose the right and profitable place of investment, while for the government this research information is expected to be used to know the conditions of the hospitality sector to conduct oversight and issue appropriate policies to improve and give new colors to the economic climate. tourism sector.

\section{Literature review}

\subsection{Capital structure}

The capital structure of a company is "the funding decision made by the financial manager in relation to how to finance the investment decision that the company will make" (Wiagustini, 2014). According to Ambarwati (2010) capital structure is "a combination or balance between debt and equity capital used by the company to plan over the debt". "Assets owned by the company can be used as collateral for the company to get additional capital. High-value assets as collateral, then the amount of additional capital that will be obtained by the company will also be large" (Sitanggang, 2013).

One of the ratios used in measuring the comparison of the proportion of debt and own capital in a company is DER (Sawir, 2004) where the DER reflects the firm's ability to meet all of its obligations, as evidenced by the proportion of capital used to pay its equity debt, in other words, this ratio is used to determine the share of capital as collateral assess the amount of debt used by the company (Malikussaleh et al., 2014).

Azmal et al. (2019) states that the ratio of DER is a ratio that reflects the company's ability to meet all its obligations, as indicated by some portion of its own capital used to pay off the company's debt.

Companies with large DER ratios must pay a smaller dividend, as the profits earned are used to pay off their obligations in advance (Fitri et al., 2016). While according to Alzomaia and Al-Khadhiri (2013) also says that companies with high financial DER tend to have low dividend payments.

\subsection{Theory of capital structure}

\subsubsection{Trade-off theory}

The theory of capital structure was first pioneered by Modigliani and Miller in 1958. One of the assumptions in a perfect market is that there is no tax. The proportion of MM is "if there is no tax, the capital structure does not affect the value 
of the company". In other words, if there is no tax, then the capital structure is irrelevance. This proportion is evidenced by the use of arbitration. In its development, Modigliani-Miller included an element of taxation, so that the capital structure became relevant, as interest paid as a result of using debt could reduce taxable income (tax deductible). The value of the company will be maximum, if the company uses $100 \%$ debt and the more debt the better, this phenomenon is called the corner optimum leverage decision.

In practice the use of $100 \%$ debt is difficult to find and this is opposed by trade-off theory. In fact, the greater the debt the higher the burden that the company must bear, due to agency costs, bankruptcy costs, refusal of creditors to give large debts, and so on. Trade-off theory, states that the optimal capital structure is achieved when there is a balance between benefits and sacrifices arising from the use of debt. The benefits of using debt in the form of tax shield. The cost of using debt is the burden of debt interest, bankruptcy costs, and agency costs. The first implication of trade-off theory according to Brealey and Myers (1991) is that companies with large business risks should use less debt than companies with low business risk, because the greater the business risk, The increased use of debt will increase the interest burden, which will further complicate the company's finances, the second is that the company that is taxed high to a certain extent should use a lot of debt due to the tax shield, while the third is the target debt ratio will differ between one company and other companies. Companies that are profitable, and tangible assets have higher debt ratio targets. Unprofitable companies with high risk and intangible assets have lower debt ratios and are more dependent on equity. while the third is target debt ratio will differ between one company and another. Companies that are profitable, and tangible assets have higher debt ratio targets. Unprofitable companies with high risk and intangible assets have lower debt ratios and are more dependent on equity. while the third is target debt ratio will differ between one company and another. Companies that are profitable, and tangible assets have higher debt ratio targets. Unprofitable companies with high risk and intangible assets have lower debt ratios and are more dependent on equity.

\subsubsection{Pecking order theory}

The pecking order hypothesis describes a hierarchy in corporate fundraising where firms prefer to use internal equity to pay dividends and implement them as growth opportunities. If a company needs external funds, it will prefer debt over external equity (Donaldson, 1961; Myers, 1984; Myers and Majluf, 1984). Internal equity is derived from retained earnings and depression. Debt is obtained from lender loans, while external equity is obtained because the company issues new shares. Myers introduced the Pecking Order Theory (POT) based on asymmetric information, if the stock price in the market is too expensive (over value) then the company must refuse to issue new shares. Because the stock price will go down as a correction/valuation process.

In short, the order of funding according to POT is (Brealey and Myers, 1991), first companies prefer internal financing; second companies adjust the target dividend payout ratio to their investment opportunities, while they avoid drastic dividend changes, third dividend policies that "Sticky" plus unpredictable fluctuations in profitability and investment opportunities, meaning that sometimes internal cash flow exceeds investment needs but sometimes less than investment needs, fourth If external funding is needed, companies will first issue the safest securities, which starts with issuance of bonds (debt), convertible bonds, the last alternative is securities.

\subsection{Profitability}

Profitability is the relationship between income and expenditure generated from the use of corporate assets (smoothly and permanently) in productive activities (Gitman and Zutter, 2012). Companies with high profitability tend to use some of the profits earned for investment and funding operations. Return on Assets (ROA) indicates the measure of a company's effectiveness in generating profits by exploiting its assets, this ratio can be an indication that management is good or bad in implementing cost control or property management. This ratio is also often used as a tool to measure the total ROA after interest or tax (Heikal et al., 2014). Asset return (ROA) reflects the ability of corporate management to generate profits from corporate assets (Chen, 2010).

\subsection{Growth}

The level of leverage is influenced by the growth rate in accordance with trade-off theory, companies that have a high growth rate tend to finance their investments by issuing shares, because the share price is relatively high. Another reason is that high-growth companies tend to bear large costs of financial distress, as they have a high risk of bankruptcy. Thus, growth rate is negatively related to leverage level. In contrast, according to POT, the growth rate has a positive relationship with the level of leverage, because it temporarily has an investment that is still too low, so it temporarily has a low level of leverage. 
Growth opportunities defined as the total book value of assets minus the value of equity books plus the market value of equity divided by the total book value of assets (Deesomsak et al., 2004). Pcompany growth can be characterized by an increase in market share and market share which has experienced a significant increase, so that companies have the opportunity to increase sales in order to generate maximum profits for the company and influence the increase in profitability. High sales growth indicates that the company has good growth prospects, thus providing greater profits related to providing good returns in the future to investors. This leads to a positive investor perception, and has an impact on increasing the value of the company (Charitou et al., 2001).

\subsection{Company size (firm size)}

Gitman and Zutter (2012) explains that size Company (size firm) is the size of the assets owned by the company including the number of assets owned by the company, it can be seen from the total assets owned by the company or the total assets of the company listed in the company's financial statements at the end of the audit period. Company size can also be measured with total sales, total asset book value, total assets, and number of jobs (Ayuningtias and Kurnia, 2013).

According to Brigham and Houston (2010) Firm Size (Firm Size) is a large size of a company that is represented or assessed with total assets, total sales, amount of profits, tax burden and other factors.

\subsection{Tangibility}

Tangibility is the amount of assets that can be used as collateral or the value of the asset's security (Sudiyatno and Sari, 2013). Guaranteed assets are assets requested by creditors as collateral for loans. Growth assets basically describe how a company invests its own funds for operating and investment activities. Increased total assets, both smooth assets and long-term assets in need of funds, with alternatives to internal or external funding (Sudiyatno and Sari, 2013). Tangibility defined as the ratio of total fixed assets to total assets (Memon, Pervaiz Ahmed et al, 2020).

The greater the tangibility of a company's assets means the more collateral assets can be used as collateral in acquiring external funding in the form of debt or equity.

\section{Hypothesis}

\subsection{Profitability (ROA) against capital structure (DER)}

The higher the firm's profits measured using ROA, the greater the firm's ability to pay its equity debt (Margaretha, 2014). Companies that have high profits, will use debt in low amounts, and vice versa. Companies that can generate greater earnings tend to use retained earnings to meet their funding needs. Research results Alipour et al. (2015) Kartikasari and Merianti (2016), Fajrida and Br.Purba (2020), Margaretha, (2014), Ramadhan et al. (2016), that there is a positive relationship between profitability and DER. that large-profit companies have good access to alternative sources of funding. This is because these profitable companies have superior information.

Based on analysis and research findings Alipour et al. (2015), Margaretha, (2014), Ramadhan et al (2016), Fajrida and Br.Purba (2020), Kartikasari and Merianti (2016), then the research hypothesis is formulated as follows:

$H_{l}:$ Return on Assets (ROA) is positively related against debt to equity.

\subsection{Company growth (growth) towards capital structure (DER)}

The larger the firm, the smaller the capital structure of the debt. Because the larger the company, the more it finances its finances using its own capital or using retained earnings or equity. So the size of the company is exactly the opposite of company leverage. In accordance with the theory of POT the size of the company is negatively related to the level of leverage of the company Deesomsak et al. (2004), Alter and Elekdag (2020), Moradi and Paulet (2019), Sakr and Bedeir (2019).

Based on research results Alter and Elekdag (2020), Deesomsak et al (2004); Moradi and Paulet (2019), Sakr and Bedeir (2019), then this research hypothesis is formulated as follows:

$\mathrm{H}_{2}$ : Growth companies are negatively related against debt to equity.

\subsection{Company size (firm size) against capital structure (DER)}

In the development of the company, the size of the company is very decisive in the need for capital to increase business so that capital is taken through debt and equity, as a result the larger the size of the company, the bigger and higher the 
need for debt and equity use. Large companies are more diversified (Titman and Wessels, 1988), easier to access capital markets, receive higher credit ratings, and pay lower interest rates (Ferri and Jones, 1979). Small companies are more likely to be liquidated when companies have difficulty repaying their debts (Ozkan, 2001). So that there is a positive relationship between the size of the company and the capital structure (Thippayana, 2014; Detthamrong et al., 2017; Baloch et al, 2015; Sakr and Bedeir, 2019; Sudiyatno and Sari, 2013; Teng and Jonnardi, 2019).

Based on research resultsThippayana (2014),Deesomsak et al. (2004); Moradi and Paulet (2019), Baloch et al. (2015), Sakr and Bedeir (2019), Sudiyatno and Sari (2013), Teng and Jonnardi (2019), then this research hypothesis is formulated as follows:

$H_{3}:$ The size of the firm is positively related against debt to equity.

\subsection{Tangibility against debt to equity}

The company's assets that are used as collateral or as collateral are assets requested by the creditor in providing the loan, this is required by the creditor to provide assurance that the company is able to repay the loan indicated by the form of collateral, so The company's ability to pay off debts and equity is also high, the impact of debt to equity is getting smaller. Alipour et al. (2015), Baloch et al. (2015), Margaretha (2014), Sudiyatno and Sari, (2013), states that tangibility has a positive effect on debt to equity, and

From the results of research conducted by Alipour et al. (2015), Baloch et al. (2015), Margaretha (2014), Sudiyatno and Sari (2013) above the author submits the following hypothesis:

$H_{3}:$ Tangibility positive against debt to equity.

From the results of the hypothesis presented above, then research on the effect of profitability, growth, firm size, tangibility on DER is moderated by inflation. The model of the hypothesis is as follows:

\section{Research methodology}

This study aims to determine the effect of profitability, growth, firm size, and tangibility and inflation as moderator variables influence the DER in hospitality companies in Indonesia by using objects and research periods in hospitality companies that publish financial reports in the period 2014 to 2019, while research data using emiten from the Jakarta stock exchange and uses financial statements published by hospitality in Indonesia out of a total of 28,230 author accommodation providers using 18 companies that can be sampled, this is because almost all hospitality companies in Indonesia are private ownership so the financial statements are closed very close to the public and limited to stakeholders only, while some hotels only have a limited annual financial report and do not enter the period 2014 -2019 so it is considered not to represent the sample.

The design carried out in this study is a quantitative approach because it requires a systematic approach to the relationship between variables that emphasizes hypothesis testing by using statistical tools to conduct the test, to test the impact of profitability, growth, firm size, and tangibility as moderator variables influence the DER.

The method used for this study is to use non-probability sampling technique that is purposive sampling, The object obtained in this study is the sample number of 18 companies that meet the requirements of their financial statements and the period 2014-2019 using regression and correlation, in addition researchers also use Normality Test, Heterosecurity Test, Multicolineoline Test, Autocorrelation Test, Determination Coefficient, Simultaneous Test ( $F$-Test), Partial Test ( $T$ Test), Regression Test Multiple to be analyzed using the help of SPSS Ver 25.0 software.

\section{Results}

The method of analysis performed to determine the shape and size of the influence of independent variables ROA, growth, firm size and tangibility on variables dependent DER is to use multiple regression processed with SPSS Version 25. To test the feasibility of the model, several tests were performed before the double regression test was performed:

\subsection{Normality test}

Visible $p$-value $>0.05$ so that the data is considered to meet the normality assumption. 
Table 1: Normality test

\begin{tabular}{|c|c|c|c|}
\hline \multicolumn{4}{|c|}{ One-Sample Kolmogorov-Smirnov test } \\
\hline & & & $\begin{array}{c}\text { Unstandardized } \\
\text { residual }\end{array}$ \\
\hline & $\mathrm{N}$ & & 90 \\
\hline \multirow[t]{2}{*}{ Normal parameters ${ }^{\mathrm{a}, \mathrm{b}}$} & Mean & & 0.0000000 \\
\hline & Std. Deviation & & 0.64922995 \\
\hline \multirow[t]{3}{*}{ Most extreme differences } & Absolute & & 0.181 \\
\hline & Positive & & 0.181 \\
\hline & Negative & & -0.117 \\
\hline Test statistic & & & 0.181 \\
\hline Asymp. Sig. $(2 \text {-tailed })^{\mathfrak{c}}$ & & & 0.108 \\
\hline \multirow[t]{3}{*}{ Monte Carlo Sig. (2-tailed) ${ }^{\mathrm{d}}$} & Sig. & & 0.056 \\
\hline & $99 \%$ Confidence Interval & Lower & 0.000 \\
\hline & & Upper & 0.000 \\
\hline
\end{tabular}

Note: ${ }^{\text {a }}$ Test distribution is Normal; ${ }^{\mathrm{b}}$ Calculated from data; ${ }^{\mathrm{c}}$ Lilliefors Significance Correction; and ${ }^{\mathrm{d}}$ Lilliefors' method based on 10000 Monte Carlo samples with starting seed 299883525.

\subsection{Heterosecurity test}

It can be seen in the scatterplot image that the points do not converge into 1 but instead scatter between 1 so that it is considered to meet the assumption of heteroscacity.






\subsection{Multicolineoline test}

It is seen that the tolerance value $>0.05$ and the value of VIF (Variance Inflation Factor) $<10$ so that there is no multicolineineity in the data.

Table 3: Multicollinearity test

\begin{tabular}{|l|c|c|}
\hline \multirow{2}{*}{ Model } & \multicolumn{2}{|c|}{ Coefficients $^{\text {a }}$} \\
\cline { 2 - 4 } & Tolerance & \multicolumn{2}{|c|}{ VIF } \\
\cline { 2 - 4 } 1. ROA & 0.975 & 1.025 \\
\hline 2. GROWTH & 0.858 & 1.166 \\
\hline 3. FIRM SIZE & 0.985 & 1.015 \\
\hline 4. TANGIBILITY & 0.838 & 1.193 \\
\hline Note: ${ }^{a}$ Dependent Variable: DER. & & \\
\hline
\end{tabular}

\subsection{Autocorrelation test}

With a total of 90 samples and four independent variables. So the values of $d L$ and $d U$ at $n=90$ and $k=4$ are 1.566 and 1.751. The Watson-Durbin value obtained in the research model is worth 1.902. The requirement for no autocorrelation is $d U<d<4-d U$, so there is no autocorrelation on the data.

\begin{tabular}{|l|c|}
\hline \multicolumn{2}{|l|}{ Table 4: Autocorrelation test } \\
\hline Model Summary ${ }^{\mathrm{b}}$ & \multicolumn{1}{|c|}{ Durbin-Watson } \\
\hline Model & 1.902 \\
\hline 1 & $d \boldsymbol{C}$ \\
\hline$d \boldsymbol{L}$ & 1.751 \\
\hline 1.566 & \\
\hline Note: Syarat tidak ada autokorelasi; $\mathrm{dU}<\mathrm{d}<4-\mathrm{dU} ; \mathrm{d}=1,902 ; 4-\mathrm{dU}=2,249$. \\
\hline
\end{tabular}

\subsection{Determination coefficient test}

In the research model, the value of $R^{2}$ is seen as 0.249 , meaning that the variables used in the research model represent $24.9 \%$ variables that can affect DER. While the rest $(75.1 \%)$ is affected by other variables.

Table 5: Determination coefficient test
\begin{tabular}{|l|c|c|c|c|}
\hline \multicolumn{5}{|c|}{ Model Summary } \\
\hline Model & $\boldsymbol{R}$ & $\boldsymbol{R}^{\mathbf{b}}$ & Adjusted $\boldsymbol{R}^{2}$ & Std. Error of the Estimate \\
\hline 1 & $498^{\mathrm{a}}$ & 0.249 & 0.216 & 0.664330335996643 \\
\hline
\end{tabular}

Note: ${ }^{a}$ Predictors: (Constant), TANGIBILITY, FIRM SIZE, ROA, GROWTH; and ${ }^{\mathrm{b}}$ Dependent Variable: DER.

\subsection{Simultaneous test (F-test)}

It can be seen that the $p$-value in the ANOVA table is 0.032 or $<0.05$ so that the independent variables are considered to be able to simultaneously affect the dependent variables. 
Table 6: Simultaneous test $(F$-test $)$

\begin{tabular}{|c|c|c|c|c|c|}
\hline \multicolumn{6}{|c|}{ ANOVA $^{a}$} \\
\hline Model & Sum of squares & $\mathrm{df}$ & Mean squares & $F$ & Sig. \\
\hline Regression & 3.646 & 4 & 0.912 & 2.065 & $0.032^{\mathrm{b}}$ \\
\hline Residual & 37.513 & 85 & 0.441 & & \\
\hline Total & 41.160 & 89 & & & \\
\hline
\end{tabular}

\subsection{Partial test (T-test)}

It can be seen in the Table, that of the four independent variables that affect the dependent variables. Only 1 variable that has an insignificant effect is ROA. While other variables such as GROWTH, FIRM SIZE and TANGIBILITY can have a significant effect on DER.

Table 7: Partial test (T-test)

\begin{tabular}{|l|c|c|}
\hline \multicolumn{2}{|c|}{ Coefficients $^{\text {a }}$} \\
\hline Model & $t$ & Sig. \\
\hline (Constant) & 0.197 & 0.844 \\
\hline ROA & -0.685 & 0.495 \\
\hline GROWTH & -1.155 & 0.041 \\
\hline FIRM SIZE & 1.197 & 0.035 \\
\hline TANGIBILITY & 1.680 & 0.037 \\
\hline Note: ${ }^{a}$ Dependent Variable: DER. & & \\
\hline
\end{tabular}

\subsection{Multiple regression test}

The results of multiple regression analysis with dependent variables of Capital Structure (DER) and four independent variables consisting of ROA, Growth, Firm Size and Tangibility produce the intercept and coefficient of regression as listed in the following table:

Table 8: Multiple regression test

\begin{tabular}{|l|l|c|c|c|c|c|}
\hline \multicolumn{7}{|c|}{ Coefficients $^{\text {a }}$} \\
\hline \multirow{2}{*}{ Model } & \multicolumn{2}{|c|}{ Unstand. Coeff. } & Std. Coeff. & \\
\hline \multirow{2}{*}{1.} & (Constant) & 0.087 & 0.441 & Beta & $t$ & Sig. \\
\cline { 2 - 7 } & ROA & -0.642 & 0.938 & -0.072 & -0.685 & 0.844 \\
\cline { 2 - 7 } & GROWTH & -0.972 & 0.841 & -0.129 & -1.155 & 0.495 \\
\cline { 2 - 7 } & FIRM SIZE & 0.032 & 0.027 & 0.125 & 1.197 & 0.041 \\
\cline { 2 - 7 } & TANGIBILITY & 0.401 & 0.238 & 0.190 & 1.680 & 0.037 \\
\hline
\end{tabular}


Based on the above research model, the formula for the above model is as follows:

$$
\begin{gathered}
\text { DER }=0,087-0,642 \text { ROA }-0,972 \text { GROWTH }+0,032 \text { FIRM SIZE } \\
+0,401 \text { TANGIBILITY }
\end{gathered}
$$

\section{Discussion}

Hypothesis testing is done by looking at the results of the analysis output in Table 4 where based on the analysis by comparing $t$-statistics with $p$-value and $t$ table so that the results of the hypothesis are as follows:

\subsection{Analysis Return on Assets (TWO)Against Debt to Equity (DER)}

The profitability variable measured with ROA in this study did not have a positive effect on the capital structure measured with debt to equity (Alipour et al., 2015; Margaretha, 2014; Ramadhan et al., 2016; Fajrida and Br.Purba, 2020; Kartikasari and Merianti, 2016). According to the hypothesis developed there is no significant relationship between profitability and leverage; trade-off theory proposes a significant positive relationship while a negative negative relationship is consistent with POT. The results of this study are not in accordance with trade-off theory which states that the higher the level of profitability of a company, then the company tends to use debt the greater.

The inconsistency of research results with this theory is due to the possibility of low profitability, so that companies use more debt and equity to finance most of the funding and investment needs.

This research is not in line with the results of research conducted by Alipour et al. (2015), Margaretha (2014), Fajrida and Br.Purba (2020), Kartikasari and Merianti (2016), Ramadhan et al (2016); Songul Kakilli Acaravci (2015) that ROA has a positive effect on the capital structure measured by DER so that the author's hypothesis rejected. While in this study in line with the results of research conducted by Moradi and Paulet (2019); Xin He (2019) who explained that profitability is not positively related to the capital structure measured using the ratio of debt to equity.

\subsection{Corporate growth relationship (growth) towards Debt to Equity (DER)}

Company growth is hypothesized to have a significant negative relationship with short-term debt to total assets. This study is in line with the POT which proposes a significant negative relationship between leverage. The results show that there is a significant negative relationship between the size of the firm and the capital structure of the DER. These results are in line with the findings of the study (Alter and Elekdag, 2020; Deesomsak et al., 2004; Moradi and Paulet, 2019; Sakr and Bedeir, 2019).

This means that when the growth of company sales is high then the company's need for debt will decrease, because the need for funding or capital structure will be met through retained earnings as well as the issuance of bonds and shares if for investment needs (Moradi and Paulet, 2019). This hypothesis is consistent with the POT that growth is negatively related to capital structure. Because the growth of large companies does not guarantee that the capital structure obtained is also large, so the greater the growth of large companies does not guarantee the higher capital structure.

So that this result proves the research that has been done by Alter and Elekdag (2020), Deesomsak et al. (2004), Moradi and Paulet (2019) that Company growth (growth) has a negative effect on DER so the author's hypothesis is accepted.

\subsection{Relationship of company size (firm size) to Debt to Equity (DER)}

Company size is often considered as a measure of the small size of a firm assessed from the total assets, equity or sales of a firm (Brigham and Houston, 2001). This study is in line with the trade-off theory which proposes a significant positive relationship between firm sizewith capital structure. Factors considered in determining funding policies in meeting the small size of hospitality company assets are the size of the company. Large hospitality companies will issue funds which is also great, both from debt policy and from own capital.The chances of a company's failure to repay the debt are also based on the size of the company, where small companies find it more difficult to get a loan compared to large companies because creditors have more confidence in large companies. It can be said that the size of the firm has an influence on the capital structure based on the larger a company, the greater the loan required.The impact of the ease of obtaining a loan owned by a large hospitality company makes the use of more loans by the company in fulfilling its investment and capital needs.

So it can be concluded that the size of the firm has an influence on the capital structure, thus these results are in line with the research that has been done by Thippayana (2014), Detthamrong et al. (2017), Baloch et al. (2015),Sakr and 
Bedeir (2019), Sudiyatno and Sari (2013), Teng and Jonnardi (2019). that firm size has a positive effect on DER until the author's hypothesis is accepted.

\subsection{The relationship of tangibility to Debt to Equity (DER)}

The tangibility variable in this study has a positive effect on the capital structure measured by DER, so this study is in line with the trade-off theory which proposes a significant positive relationship between tangibility with capital structure. The assets of the hospitality company are mostly land and building assets so that the asset can be used as collateral or collateral by the hospitality company. The greater the tangibility proportion of hospitality company assets makes creditors provide high confidence and ease in lending, so that the company's debt level becomes large (Bonfi and Antão, 2012). This research is supported by size effect theory where companies with smooth tangibility to large debts will be easier to get a loan flow compared to companies that do not have collateral on debt (Brigham and Joel, 2011).

Therefore, the results of this study explain that tangibility has a positive relationship to the capital structure of the company, and this result is in line with the research conducted by acquire Alipour et al. (2015), Baloch et al. (2015); Margaretha (2014); Sudiyatno and Sari (2013) that tangibility has a positive effect on DER so that the author's hypothesis is accepted.

\section{Conclusion}

From the results of research conducted by the author can be explained that variable profitability (ROA) has no effect on Capital Structure (DER), while variable growth, firm size, tangibility has a significant effect on capital structure (DER) so explains that the capital structure of a hospitality company will be affected by its growth, size and tangibility, while the inflation moderation variable has no influence between the profitability variable (ROA) and firm size on the capital structure (DER) so it can be explained that the inflation variable does not affect both this variable.

\section{Limitations}

Research on DER (Capital Structure) measured with debt to equity in an effort to increase profits is very interesting to study, but there are still many other factors that affect it, it is seen in this study that the variables used in measurement using 1 measuring instrument only although it has used independent and moderation variables but from testing it is known that there are still some limitations because there are still other measuring instruments that also affect the DER, in addition to this study the sample studied is limited to hospitality companies and if done in other industries is expected can produce different hypotheses and analyzes as well.

\section{Suggestions for further research}

From the limitations of this study, the researcher gives suggestions to further researchers to add other moderation variables such as currency exchange rates and other measuring instruments as random factors that may affect the capital structure and examine the direct relationship of these variables with debt to equity. In addition, it is also necessary to conduct research for industries other than manufacturing and other than hospitality.

\section{Managerial implications}

Managerial implications in this study the author describes in detail as follows:

1. Hospitality companies should maintain and manage and manage so that the growth of the company and the size of the company in accordance with the Capital Structure (DER), do not let the company grow too fast but use debt (debt) too large for equity so it can not meet its obligations.

2. Companies in order to manage tangible assets well, avoid until there are many tangible assets but not able to generate profit.

\section{References}

Ajao, O., Ema, I. and Sunday. (2012). Determinants of Capital Structure in Nigerian Firms.

Alipour, M., Mohammadi, M. farhad S. and Derakshan, H. (2015). Article information: Determinants of capital stucture: an empirical study of firms in Iran. International Journal of Law and Management Emerald Insight, 57(1), 53-83. https://doi.org/http://dx.doi.org/10.1108/IJLMA-01-2013-0004

Alter, A. and Elekdag, S. (2020). Emerging market corporate leverage and global financial conditions. Journal of Corporate Finance, 62 (August 2018), 101590. https://doi.org/10.1016/j.jcorpfin.2020.101590 
Alzomaia, T.S. and Al-Khadhiri, A. (2014). Analysis of factors that impact dividend payout ratio on listed companies at Jakarta islamic index. International Journal of Academic Research in Accounting, Finance and Management Sciences. 6(2), 87-97. https://doi.org/10.6007/ijarafms/v6-i2/2074

Alzomaia, T.S. and Al-Khadhiri, A. (2013). Determination of dividend policy: the evidence from Saudi Arabia. International Journal of Business and Social Science, 4(1), 181-192.

Ambarwati, S.D.A. (2010). Advanced Financial Management. Yogyakarta: Graha Ilmu.

Ayuningtias, D. and Kurnia. (2013). Effect of profitability on company value: dividend policy and investment opportunity as variable between. Journal of Accounting Science and Research, 1(1), 37-57.

Azmal, R., Negoro, D.A., Yanuar, T. and Syah, R. (2019). The influence cash position analysis over debt to equity ratio, return on assets, and inventory turnover on dividend payout ratio: consumer goods companies in Indonesia Stock Exchange 2012-2017 case study.

Baloch, Q.B., Ihsan, A., Kakakhel, S.J. and Sethi, S. (2015). Impact of firm size, asset tangibility and retained earnings on financial leverage: evidence from auto sector, Pakistan. Abasyn Journal of Social Sciences. 8(1), 143-155.

Bodie, Z., Kane, A. and Marcus, A. (2008). Essentials of Investments (7th ed). New York: McGraw Hill.

Bonfi, D. and Antão, P. (2012). The Dynamics of Capital Structure Decisions.

Brigham, E.F. and Houston, J.F. (2009). Fundamentals of Financial Concise. Sixth Edition.

Brigham, F. and Joel, H. (2011). Fundamentals of Financial Management. Second Book, Edition 11 (Translate Ali Akbar Yulianto). Jakarta: Salemba Empat. (11th ed.). Jakarta Office.

Charitou, A., Clubb, C. and Andreou, A. (2001). The effect of earnings permanence, growth and firm size on the usefulness of cash flows and earnings in explaining security returns: Empirical evidence for the UK. Journal of Business Finance and Accounting, 28 (5-6), 563-594. https://doi.org/10.1111/1468-5957.00385

Chen, M.H. (2010). The economy, tourism growth and corporate performance in the Taiwanese hotel industry. Tourism Management, 31(5), 665-675. https://doi.org/10.1016/j.tourman.2009.07.011

Deesomsak, R., Paudyal, K. and Pescetto, G. (2004). The determinants of capital structure: Evidence from the Asia Pacific region. Journal of Multinational Financial Management, 14(4-5), 387-405. https://doi.org/10.1016/ j.mulfin.2004.03.001

Detthamrong, U., Chancharat, N. and Vithessonthi, C. (2017). Corporate governance, capital structure and firm performance: Evidence from Thailand. Research in International Business and Finance Elseviers, 42 (September 2016), 689-709. https://doi.org/10.1016/j.ribaf.2017.07.011

Fajrida, S. and Br.Purba, N.M. (2020). The effect of profitability, company size and asset growth on the capital structure of companies in the Indonesian stock exchange. EMBA Journal: Journal of Economic Research, Management, Business and Accounting, 8(1), 627-636. https://doi.org/10.35794/emba.v8i1.28019

Fitri, R.R., Hosen, M.N. and Muhari, S. (2016). Analysis of factors that impact dividend payout ratio on listed companies at Jakarta islamic index. International Journal of Academic Research in Accounting, FInance and Management Sciences. 6(2), 87-97. https://doi.org/10.6007/IJARAFMS/v6-i2/2074

Gantino, R., Ruswanti, E. and Rachman, T. (2017). Performance model: Environmental uncertainty, decentralization of authority and business strategy on managerial performance (Property and Real Estate and Food and Beverage Sectors Listed on Indonesia Stock Exchange). International Journal of Economic Research, 14(12), 151-163.

Gitman, L.J. and Zutter, C.J. (2014). Determinants of debt policy in Indonesia 's public company. Review of Integrative Business \& Economics Research, 3(2), 10-16.

Gitman, L.J. and Zutter, C.J. (2012). Principles of managerial finance. In The Journal of Finance (13th ed, Vol. 17). https:/ /doi.org/10.2307/2977800

Heikal, M., Khaddafi, M. and Ummah, A. (2014). Influence Analysis of Return on Assets (ROA), Return on Equity (ROE), Net Profit Margin (NPM), Debt To Equity Ratio (DER), and current ratio (CR), against corporate profit growth in automotive in Indonesia stock exchange. International Journal of Academic Research in Business and Social Sciences, 4(12). https://doi.org/10.6007/ijarbss/v4-i12/1331

Hoopes, D., Madsen, T. and Walker, G. (2003). Why is there a resource-based view? Toward a theory of competitive heterogeneity. Strategic Management Journal, 24(10), 889-902. 
ILO. (2009). Implications of the global economic crisis for tourism employment: case study for Indonesia. Jakarta Office.

Jagels, M. (2007). Hospitality management accounting (9th ed). John Wiley and Son.

Kartikasari, D. and Merianti, M. (2016). The effect of leverage and firm size to profitability of public manufacturing companies in Indonesia. International Journal of Economics and Financial Issues, 6(2), 409-413.

Khan, Z.S. (2010). Determinants of capital structure: Case of listed paint manufacturing companies. Interdisciplinary Journal of Contemporary Research in Business, 2(6), 253.

Malikussaleh, U., Khaddafi, M. and Malikussaleh, U. (2014). Influence analysis of Return on Assets (ROA), Return on Equity (ROE), Net Profit Margin (NPM), Debt To Equity Ratio (DER), and current ratio (CR), against corporate profit growth in automotive in Indonesia stock exchange. (January 2016). https://doi.org/10.6007/IJARBSS/v4i12/1331

Margaretha, F. (2014). Determinants of debt policy in Indonesia 's public company. Review of Integrative Business \& Economics Research, 3(2), 10-16.

Moradi, A. and Paulet, E. (2019). The firm-specific determinants of capital structure - An empirical analysis of firms before and during the Euro Crisis. Research in International Business and Finance. Elsevier, 47, 150-161. https:// doi.org/10.1016/j.ribaf.2018.07.007

Nurlinda, R.A. and Lucky, E. (2019). Financial performance information as forming corporate failure model in Indonesia. Academy of Accounting and Financial Studies Journal, 23 (Special Issue 1), 1-9. https://doi.org/1528-2635-23SI-1-349

Nwaobia, A.N., Ajibade, A.T., Jayeoba, O.O. and Ajibade, A.T. (2016). Financial reporting quality on investors' decisions. International Journal of Economics and Financial Research, 2(7), 140-147.

Purwomarwanto *, Y.L. and Ramachandran, J. (2015). Performance of tourism sector with regard to the global crisis - a comparative study between Indonesia, Malaysia and Singapore. The Journal of Developing Areas, 49(4), 325339. https://doi.org/10.1353/jda.2015.0149

Ramadhan, Margaretha, F. and Rizky, A. (2016). Factors affecting the capital structure of manufacturing companies in the Indonesian stock exchange. Journal of Benefit, 1(2), 119-130. https://doi.org/10.22216/jbe.v1i2.1429

Ribeiro, P., Godinho, M., Abranja, N., Rosário, M., Justino, T. and. (2019). The relevance of tourism in financial sustainability of hotels. European Research on Management and Business Economics, 25(3), 165-174. https://doi.org/10.1016/ j.iedeen.2019.07.002

Sainaghi, R. (2014). A meta-analysis of hotel performance. Continental or worldwide style? Tourism Review, 65(3), 4669. https://doi.org/10.1108/16605371011083521

Sakr, A. and Bedeir, A. (2019). Firm level determinants of capital structure: Evidence from Egypt. International Journal of Financial Research, 10(1), 68-87. https://doi.org/10.5430/ijfr.v10n1p68

Sudiyatno, B. and Sari, S.M. (2013). Determinants of debt policy: An empirical studying Indonesia stock exchange. Educational Research, 4(2), 98-108.

Susilawati, D. and Rakhman, F. (2018). The effect of ownership structure and investor protection to firm value: Analyst following and as moderating variable. Journal of Accounting and Investment, 19(1), 64-75. https://doi.org/10.18196/ jai.190192

Tabash, MI (2017). The role of tourism sector in economic growth: An empirical evidence from Palestine. International Journal of Economics and Financial Issues, 7(2), 103-108.

Teng, A. and Jonnardi. (2019). Factor analysis - factors affecting capital structure with inflation as a moderation variable. $\mathrm{I}(2), 145-152$.

Thippayana, P. (2014). Determinants of capital structure in Thailand. Procedia - Social and Behavioral Sciences Elseviers, 143, 1074-1077. https://doi.org/10.1016/j.sbspro.2014.07.558

Viriya, H. and Suryaningsih, R. (2017). Determinant of debt policy: Empirical evidence from Indonesia. Journal of Finance and Banking Review, 2 (1), 1-8. 
Wheelen, T., HUnger, D., Hoffman, A. and Bamford, C. (2015). Strategic management corporate and business policy: Globalization, innovation and sustainability (14th ed). USA: Pearson.

Wiagustini, N.L.P. (2014). Fundamentals of financial management. First Print. Denpasar: Udayana University Press. 